\title{
The Effects of Ownership Structure on Corporate Financing Decisions: Evidence from Stock Market Liberalization
}

\author{
THOMAS O'CONNOR AND THOMAS FLAVIN \\ Department of Economics, Finance, and Accounting, National University of Ireland \\ Maynooth, Maynooth, Co. Kildare, Ireland
}

\begin{abstract}
We analyze the impact of firm-specific stock market liberalization events on the capital structure and debt maturity decisions of firms from emerging market economies. We differentiate between firms based on their ownership structures at the time of liberalization and analyze their post-liberalization behavior regarding corporate financing decisions. Our empirical results show that single-class-share firms (typically with stronger corporate governance and better information environments) respond differently to their dualclass-share counterparts. Liberalization results in lower debt reliance for the former group while the latter lengthen the maturity of their debt portfolios.

Jel Classification: F30; G15; G32.
\end{abstract}

\section{INTRODUCTION}

Programs aimed at promoting financial market integration through the elimination of barriers to international investment have long been advocated for emerging market economies. These programs have been undertaken both at the country and corporate level. The latter being the result of achieving 'investable' status through corporate reforms or by international cross-listing on a larger, more developed exchange. The extant literature documents the realized benefits of such programs as improved operating performance, greater access to finance and accelerated corporate growth (see among others, Lins et al. 2005 and Khurana et al. 2008 for the cross-listing approach; Henry, 2000 and Mitton, 2006 for the investability route; and Flavin and O'Connor, 2010 for the sole and joint effects of the alternative paths to liberalization). Typically, the empirical literature treats all firms as equal (by controlling for firm-specific characteristics) and reports results for the average firm. Recently, a number of studies, e.g. Bae and Goyal (2010) and Mitton and O'Connor (2012), have reported heterogeneous responses to liberalization programs across firms with different operating structures prior to the event. We extend this line of research to corporate financing decisions by analyzing if pre-liberalization ownership structures, and 
associated differences in corporate governance and information environments, may potentially result in heterogeneous responses post liberalization.

In particular, we analyze changes to corporate financing decisions - capital structure and debt maturity - of emerging market firms in the aftermath of firm-specific liberalizations. This issue has already attracted attention, but our main innovation is to take account of differences in pre-liberalization ownership structures and analyze if these result in differing post-liberalization responses. Pindado and De la Torre (2011) provide a theoretical framework (and supporting empirical evidence) in which ownership structures influence firms' capital structures. Chen et al. (2012) show that for US firms, there are significant differences in both debt maturity and leverage ratios between family- and non-family-owned firms. We compile a sample of 1382 firms from 24 emerging economies and divide firms into two groups; 'single-class-share' (SC) and 'dualclass-share' (DC) firms. Durnev and Kim (2005) show that in firms where control rights exceed cashflow rights (e.g. DC firms), corporate governance standards tend to be lower than in firms where no (or much smaller) differences exist between control and cashflow rights (e.g. SC firms). ${ }^{1}$ Governance problems, arising from DC structures are common in emerging markets (see Claessens et al. 2002; and Lins, 2003). Because cashflow and voting rights are separated under such a mechanism (in contrast to a one-share-one-vote system), controlling shareholders can expropriate wealth from the firm for their own benefit at very low personal cost (see DeAngelo and DeAngelo 1985; Grossman and Hart 1988; and more recently, Masulis et al. 2009). It has also been shown that DC firms have more acute informational asymmetries than SC firms (see Lim 2010; and Li et al. 2012). Such agency and informational costs can impose greater financing constraints on DC firms and results in higher costs of capital as investors often demand a larger premium to hold their stock (see Claessens et al. 2002; Lins 2003; Durnev and Kim 2005). Therefore treating SC and DC firms as equal may mask important differences in corporate financing because of their ownership structures and their associated levels of corporate governance and information asymmetries. Based on the extant theoretical and empirical literature, we develop testable hypotheses as to how financial liberalization is expected to influence corporate financing decisions and how differences are likely to emerge between firms with different ownership structures.

Therefore, our study synthesizes two areas of research, namely the relationship between financial liberalizations and corporate capital and debt maturity structure; and that between corporate transparency (governance and information regimes) and debt maturity. Recent empirical evidence suggests that capital and debt maturity structures are likely to be influenced by the quality of corporate governance (e.g. Jiraporn et al. 2012) and by informational asymmetries (e.g. Bharath et al. 2009). Hence, stock market liberalizations may impact

1 Li and Zaiats (2012) examine the corporate governance structures of dual-class share firms, and show that some of these firms do adopt what would commonly be accepted as desirable governance practices. 
firms differently when different ownership structures are in place prior to the event. These liberalizations have the potential to strengthen corporate governance and increase the disclosure of information by improving managerial accountability and the protection afforded to shareholders (see Kim and Singal 2000). ${ }^{2}$ If this is correct, and Bae et al. (2006) support this view, we should then expect to see changes in firms' capital structures in the direction implied by improvements in corporate governance and/or a reduction in information asymmetries. Chen et al. (2012) find that improvements in transparency produce differential effects for family and non-family firms, with stronger effects found for the former. Combining the findings from these two areas provides motivation for analyzing the role of pre-liberalization ownership structures in determining firms' responses in relation to financing decisions subsequent to achieving 'investable' status. Our empirical results support our hypotheses; pre-liberalization ownership structures do influence the financing decisions of SC and DC firms post-liberalization, but not in a homogeneous manner.

The rest of the article proceeds as follows. Section 2 develops testable hypotheses regarding the expected post-liberalization changes to corporate financing behavior. Section 3 describes the data, while section 4 discusses the econometric methodology and reports our empirical findings. Section 5 presents a number of robustness checks, while section 6 concludes.

\section{DEVELOPING TESTABLE HYPOTHESES}

We are guided by the existing theoretical and empirical literature in developing testable hypotheses regarding the behavior of SC and DC firms post liberalization. Our first hypothesis concerns the capital structure of all firms and is stated as follows;

Hypothesis 1: Investability is associated with reduced dependence on debt financing for all firms.

The act of being deemed investable can impact on the financing behavior of firms through two distinct - but potentially related - channels. Firstly, investability is associated with better corporate governance. Improvements in corporate governance reduce the agency costs between minority stakeholders and the controlling majority and thus reduce the need for leverage to mitigate such costs (Jensen and Meckling, 1976; and Grossman and Hart, 1982). Jiraporn et al. (2012) provide empirical evidence that better corporate governance leads to lower dependence on debt financing. Secondly, liberalization events are also associated with improvements in the information environment. Prior research (Lang et al. 2003; Bae et al. 2006) has documented that cross-listings and stock market liberalizations improve firms' information environment. From the

2 Aggarwal et al. (2011) and Ferreira and Matos (2008) emphasize the role played by foreign institutional investors in improving corporate governance. 
pecking-order theory of financing behavior (Myers and Majluf 1984), reducing information asymmetries may also alter the capital structure of firms by decreasing the relative importance of debt in favor of more information-sensitive equity. Bharath et al. (2009) present empirical evidence that information asymmetries are an important determinant of capital structure decisions. Therefore both channels reinforce each other and are arguably interrelated, because improvements in corporate governance are likely to lead to greater transparency and fewer information asymmetries. Indeed, Armstrong et al. (2012) show that governance improvements lead improvements in a firm's information environment. Consequently, we expect investability to be associated with lower debt dependence for both SC and DC firms.

Our second hypothesis focuses on the composition of firms' debt portfolios.

Hypothesis 2: Investability is associated with a lengthening of the maturity of debt portfolios for all firms.

As with our first hypothesis, both the corporate governance and information channels underpin this hypothesis. The reduction in agency costs associated with the former will alleviate the need for short-term debt to act as a monitoring device and may result in a shift toward long-term debt whose more infrequent rollovers reduce the monitoring benefits of debt. As before, the information channel predicts a similar shift in financing behavior. Because long-term debt is more information sensitive than short-term debt, the pecking order theory implies that firms will re-balance their debt portfolios toward longer maturity debt instruments as information asymmetries are reduced. Thus we expect that investability will be associated with increases (decreases) in long- (short)-term debt financing.

Our final hypothesis predicts differential effects on corporate financing decisions for SC and DC firms, thus making the pre-liberalization ownership structure an important factor in post-liberalization behavior.

Hypothesis 3: Investability may be associated with differential effects on the corporate structures of firms with different pre-liberalization ownership structures. Post-liberalization, all firms will move along the financing hierarchy but not necessarily in a homogeneous way.

This prediction relies heavily on the observation that these firms are different before the event and thus their ability to reap the rewards of investability may be impacted by their initial conditions. Recent empirical literature documents differential outcomes to liberalization programs between firms with different operating structures and restrictions prior to the event. Bae and Goyal (2010) show that firms with better governance regimes before the event reap the greatest benefits of stock market liberalizations, while Mitton and O'Connor (2012) find that pre-liberalization levels of financing constraints influence valuation gains subsequent to liberalization.

Claessens et al. (2002) and Lins (2003), among others, suggest that governance and informational deficiencies are particularly relevant for emerging market economies. Therefore, the hypothesized post-liberalization behavior is 


\section{Effects of Ownership on Corporate Financing}

again based on how investors respond to firms reducing agency costs and information asymmetries. Both types of firms will move toward instruments that are more information sensitive and offer reduced monitoring benefits. SC firms, who enjoy a higher quality of corporate governance and information transparency before the event, are better positioned to take advantage of their newly achieved investable status. Given that SC firms have better governance and greater information disclosure, they are likely to be further along the financing hierarchy when investability is achieved and hence, the liberalization event is expected to be associated with a substitution of debt for equity financing. In contrast, DC firms are likely to experience greater financing restrictions pre-investability because of the problems associated with this ownership model. Hence, DC firms are more reliant on short-term debt, which is best at mitigating agency costs and is least sensitive to informational asymmetries. Therefore the liberalization event may not immediately allow them to replicate the behavior of their SC counterparts. While we anticipate a move along the pecking order, the step from short- to long-term debt financing may be more feasible than directly accessing equity markets. Investability will help to alleviate the problems associated with this ownership structure, but may not fully overcome the agency and informational costs connected to it.

\section{DATA DESCRIPTION}

We collect data on a large sample of firms from all emerging economies with at least one 'investable' firm over the period 1980-2000. From this we identify all firms that were deemed investable over our sample period using the 'investable' measure from the International Finance Corporation (IFC) Emerging Market Database. A firm is deemed to be investable if its stock is free from country-level and firm-level restrictions on foreign investment. Furthermore, stocks are required to have sufficient size and liquidity to be realistically available to foreign investors. We categorize a firm as investable in a given year if its stock appears in the IFC investable index by December of that year. For inclusion in our final sample, a number of conditions must be fulfilled. First, firms must have (financial) data available in both the pre- and post-investable periods. All firms (investable and non-investable) must have a minimum of 3 years financial data and, in addition, non-investable firms must have at least 1 year of data available prior to the median year in which firms first become investable in their native country. Following the imposition of these requirements, our final sample comprises of 1382 firms from 24 countries. Four hundred and two firms are investable and 980 are non-investable. India provides the largest number of firms (223) and Slovakia the least (4). The greatest number of investable firms comes from Malaysia (63), while Sri Lanka has just one investable firm. Full details of the sample are given in Table 1.

Firms are classified as either SC or DC using the 'Currently a Multiple Share Company' identifier from Worldscope. Multiple share companies are defined as '. . companies which currently have more than one type of common/ordinary 
International Review of Finance

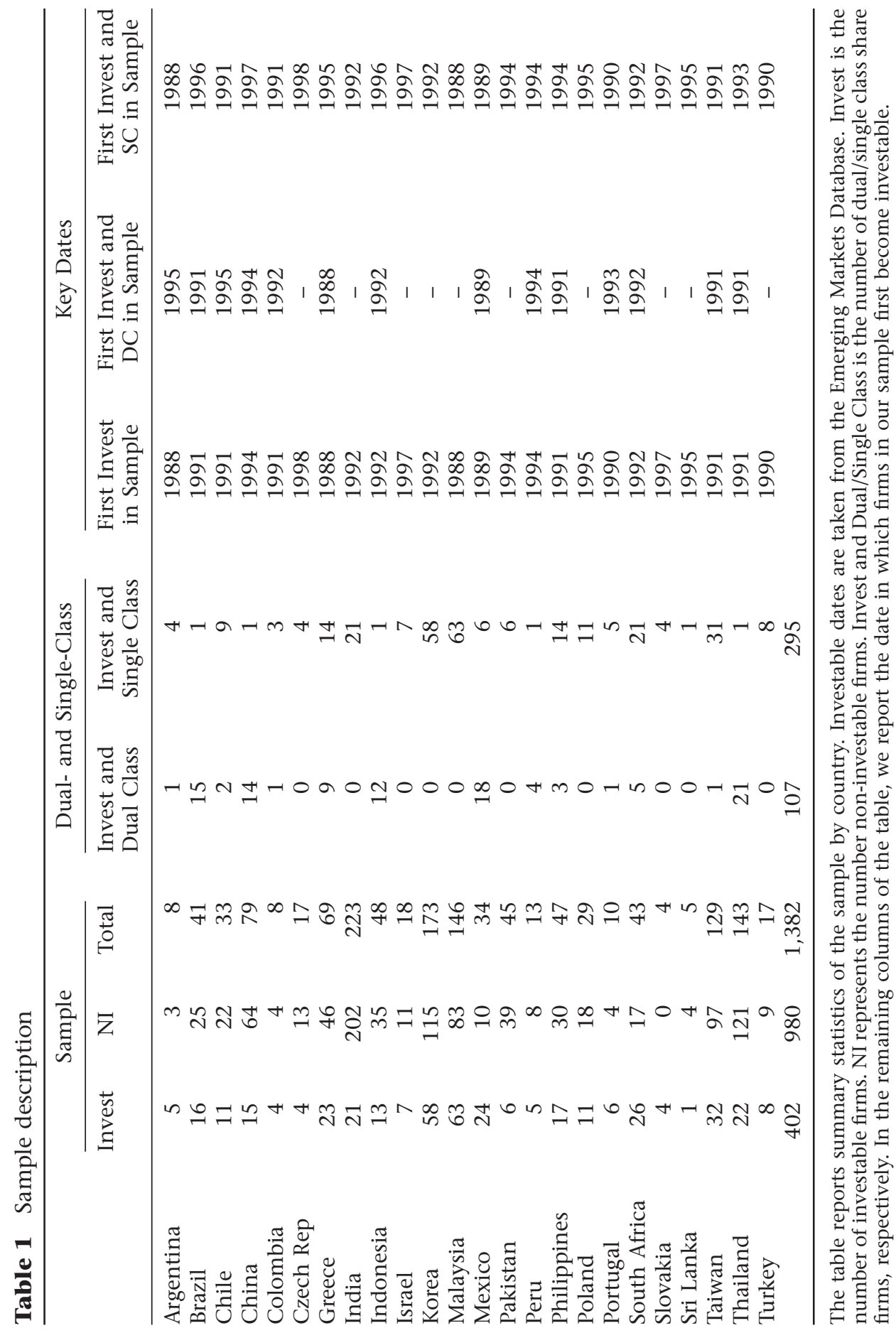


share. ${ }^{3}$ Our sample contains 107 DC and 295 SC investable firms. All countries have at least one investable SC firm with Malaysia (63) and Korea (58) together accounting for over $41 \%$ of these firms. Mexico provides the greatest number of investable DC firms (18), although many countries have none.

The final columns of Table 1 report the year in which firms first become investable. The first SC and DC firms both became investable in 1988. There is considerable variation across countries, e.g. the first Argentine, Greek and Malaysian firms became investable in 1988, while firms from the Czech Republic (1998) became investable much later.

In our analysis, we employ two widely used measures of corporate debt; namely 'Book Debt', (the ratio of total debt to total book assets), and 'Net Debt', (total debt less cash to total assets). We capture firms' debt maturity structure using long- and short-term debt to assets, long- and short-term debt to equity, and long-term debt to total debt. We also analyze the effect of investability on corporate capital structure (total debt to equity). Following convention, we exclude financial firms from our final sample and control for firm-specific factors commonly employed in related studies (see Schmukler and Vesperoni 2006; Agca et al. 2007; Mitton 2007). ${ }^{4}$ Profitability is calculated as the ratio of earnings before interest, taxation, depreciation and amortization (EBITDA) to total assets; growth opportunities as the ratio of market-to-book value of assets; tangibility as the ratio of fixed to total assets; and firm size as the log of sales (inflation-adjusted and in \$US). ${ }^{5}$ All variables are sourced from Worldscope and are winsorized at the 1 st and 99 th percentiles.

\section{REGRESSION ESTIMATES}

\section{A. Econometric methodology}

Normally, in these situations, we would use a fixed-effects model to estimate the effect of investability on the debt and debt maturity structures of firms, while controlling for other factors. However, the specification we would like to adopt here has a time-invariant variable, the DC firm dummy, which is crucial to the analysis, and therefore a traditional fixed-effects model is not very useful. Therefore, we adopt a relatively new estimation technique, which is designed to

3 Durnev and Kim (2005) classify DC firms as those whose control/voting rights exceed cash flow rights by at least $10 \%$. Because we do not have access to ownership data, we rely on the Worldscope classification.

4 Barclay and Smith (1995) and Datta et al. (2005) restrict their sample to firms with Standard Industry Classification codes between 2000 and 5999. Without access to these codes, we use the general industry classification data item provided by Worldscope and assign firms to one of six industrial groups: industrial, utility, transportation, bank/savings and loan, insurance, and other financial. To be consistent with others, we only use the first three classifications.

5 We prefer to use sales, rather than total assets to proxy for firm size, since the latter is used to construct all of the firm-level variables employed in the analysis. The results are similar when we use total assets to proxy for firm size. 
allow for the inclusion of time-invariant variables; namely, the fixed-effects vector decomposition (FEVD), which was proposed and developed by Plumper and Troeger $(2007,2011){ }^{6}$

This approach proceeds in three steps. In the first step, the (firm) fixed effects are retrieved from a fixed-effects regression:

$$
Y_{\mathrm{it}}=\alpha+\beta X_{\mathrm{it}}+\text { Year }_{\mathrm{t}}+\mu_{\mathrm{i}}+e_{\mathrm{it}}
$$

where the dependent variable is one of the debt or debt maturity ratios outlined earlier for firm $i$ in year $t$. $X_{\text {it }}$ is a set of firm-level controls (size, profitability, growth opportunities and tangibility), and Year $_{\mathrm{t}}$ is a complete set of year dummies. ${ }^{7} \mu_{\mathrm{i}}$ captures the unit or firm-fixed effects. Indeed it captures all the time-invariant factors, both observable and unobservable, that might be included in the model. In the second stage, we run an ordinary least squares (OLS) regression of these fixed effects on the time-invariant variables.

$$
\hat{\mu}_{\mathrm{i}}=v+\beta D C_{\mathrm{i}}+\varepsilon_{2 \mathrm{i}}
$$

Hence, the estimated fixed effects are decomposed into a part explained by the time-invariant variable i.e. the dual-class dummy, and an unexplained part, captured by the error term from this second stage regression. The unexplained component contains all other time-invariant factors, such as country and industry effects, and these enter into the third stage through the inclusion of this 'error term' from (2). The final stage is then estimated by pooled OLS and includes all time-variant and invariant variables:

$$
Y_{\mathrm{it}}=\alpha+\beta_{1} X_{\mathrm{it}}+\beta_{2} \text { Investable }_{\mathrm{it}}+\beta_{3} \text { Investable }_{\mathrm{it}} \times D C_{\mathrm{i}}+\beta_{4} D C_{\mathrm{i}}+\text { Year }_{\mathrm{t}}+\varepsilon_{2 \mathrm{i}}+\varepsilon_{\mathrm{it}}
$$

where in addition to the variables defined earlier, $D C_{\mathrm{i}}$ is a dummy variable that takes the value of 1 for a DC firm and zero for a SC firm; Investable $e_{\mathrm{i}, \mathrm{t}}$ is a dummy variable, which equals one if the firm is deemed investable in year $t$, and (Investable $e_{\mathrm{i}, \mathrm{t}} \times D C_{\mathrm{i}}$ ) is the interaction of the investable and dual-class dummy. All regressions are estimated with standard errors clustered at the firm level. ${ }^{8}$ Here the coefficient $\beta_{2}$ captures the average impact of investability for SC firms on the dependent variable, while $\beta_{4}$ captures the average impact of being a DC firm. For a DC firm, the total effect of becoming investable is given by $\beta_{2}+\beta_{3}$. All the effects are measured relative to the omitted benchmark group, i.e. SC noninvestable firms.

6 Others to use the FEVD approach include Lensink and van der Molen (2010), Davies et al. (2008), and Akhter and Daly (2009).

7 We follow Lensink and van der Molen (2010) by including time fixed effects (year dummies) in both the first and third steps of the FEVD regressions.

8 Plumper and Troeger (2007) suggest that estimating stage 3 by pooled ordinary least squares requires that heteroscedasticity and serial correlation be dealt with. Hence, we correct the standard errors for potential clustering across firms. Clustered standard errors are, by construction, robust to heteroscedasticity. 


\section{Effects of Ownership on Corporate Financing}

As with many issues in corporate finance, ${ }^{9}$ the potential problem of endogeneity makes it difficult to infer a causal relationship in our analysis. The ideal solution would be to use an Instrumental Variable estimation approach, but it is difficult to identify a suitable instrument for the investable dummy. Instead we concentrate our efforts on ensuring that we minimize cross-sectional differences between investable and non-investable firms. We include firm fixedeffects in our estimations to control for the time-invariant firm characteristics, while also including a number of observable firm-specific variables to control for time-varying firm effects. Mitton (2006) adopts a similar approach to minimize cross-sectional differences, leaving the investable dummy to pick up 'within-firm or time-series variation'. Admittedly, we cannot be certain that all cross-sectional differences have been eliminated so we prefer to interpret our results as showing how liberalization is associated with changes to the capital structure rather than claiming causality.

\section{B. Pre-liberalization financing patterns}

Before we test our hypotheses, we must first establish that pre-liberalization SC and DC firms are indeed different as suggested by the theoretical and empirical literature reviewed earlier. Given the importance of these pre-liberalization differences for hypothesis 3, we want to confirm that these patterns are also present in our data. Table 2 presents results from regressing our dependent variables on a DC dummy and the relevant control variables for all pre- and non-investable firms. As expected, we see differentiating features between SC and DC firms, consistent with the greater expropriation risk borne by investors in the latter group. DC firms have higher leverage ratios, while there are also important differences in debt maturity structure. In particular, DC firms employ more (less) short- (long-) term debt and this is consistent with DC firms being further down the pecking order of finance and/or investors requiring greater monitoring of these firms. Similarly, Guney and Ozkan (2005) find that the greater the wedge between cashflow and control rights, i.e. deviations from one-share one vote, the greater the use of short-term debt. They suggest that this is a voluntary decision to mitigate the agency costs associated with such an ownership structure.

\section{Testing our hypotheses}

Our coefficient estimates from estimating Eq. (3) with either book debt or net debt as the dependent variable are presented in Table 3. Primarily, we focus on the coefficients on the dummy variables and the interaction term. These results provide mixed empirical support for our first hypothesis, namely that investability is associated with lower dependence on debt financing. For SC firms,

9 Roberts and Whited (2012) provide a survey of the extent of endogeneity problems in empirical corporate finance. 


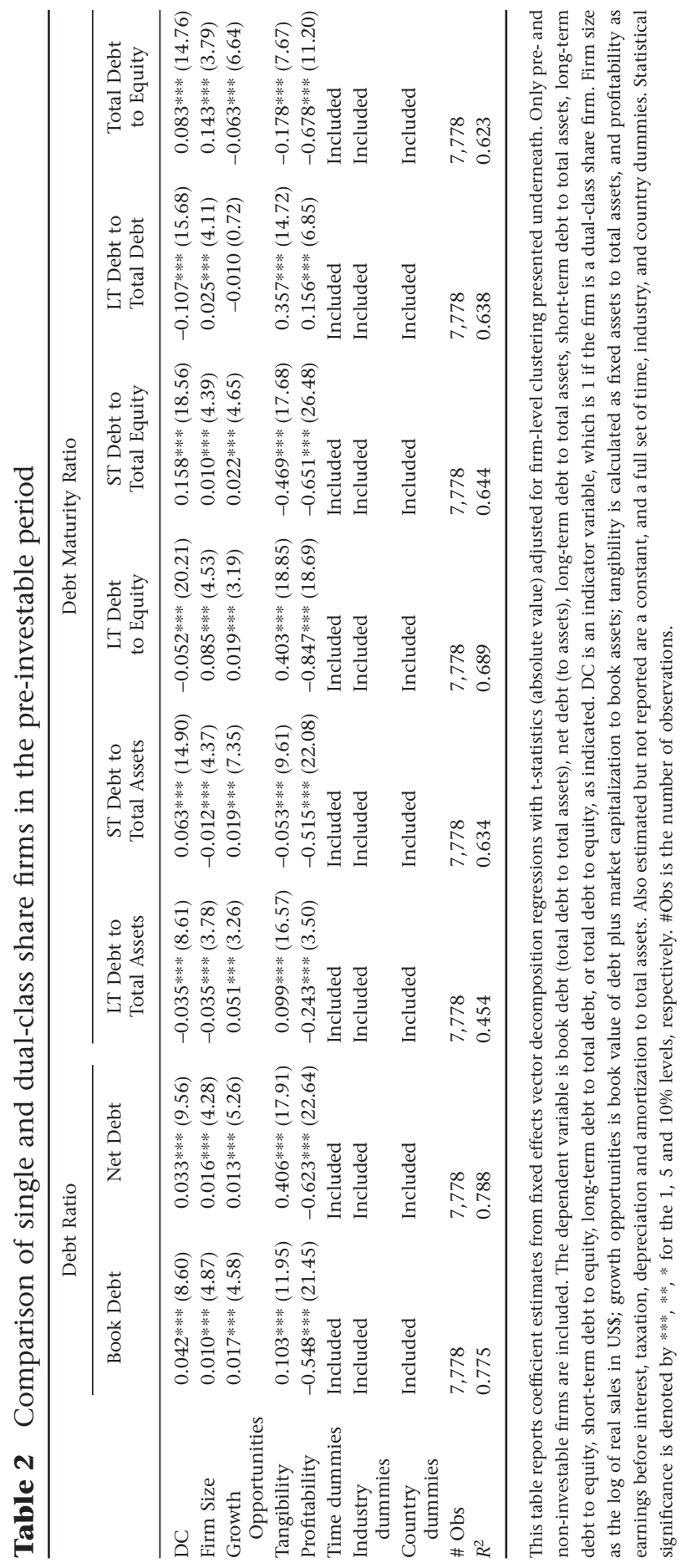




\section{Effects of Ownership on Corporate Financing}

Table 3 Investability, debt and dual-class firms

\begin{tabular}{lcc}
\hline & \multicolumn{2}{c}{ Debt Ratio } \\
\cline { 2 - 3 } & \multicolumn{1}{c}{ Book Debt } & \multicolumn{1}{c}{ Net Debt } \\
\hline Investable & $-0.011^{* * *}(3.68)$ & $-0.015^{* * *}(4.10)$ \\
Investable $\times$ DC & $0.003(0.55)$ & $0.006(1.03)$ \\
DC & $0.042^{* * *}(11.51)$ & $0.029^{* * *}(5.96)$ \\
Firm size & $0.011^{* *}(2.16)$ & $0.020^{* * *}(3.67)$ \\
Growth opportunities & $0.011^{* * *}(2.90)$ & $0.010(1.62)$ \\
Tangibility & $0.087^{* * *}(3.19)$ & $0.421^{* * *}(11.62)$ \\
Profitability & $-0.529^{* * *}(15.15)$ & $-0.614^{* * *}(15.93)$ \\
Time dummies and time-invariant effects & Included & Included \\
F-stat (investable + investable $\times$ DC) & 0.31 & 0.07 \\
\# Obs & 9,803 & 9,803 \\
$R^{2}$ & 0.769 & 0.782 \\
\hline
\end{tabular}

This table reports coefficient estimates from fixed effects vector decomposition regressions with $t$-statistics (absolute value) adjusted for firm-level clustering presented underneath. The dependent variable is book debt (total debt to total assets) or net debt (to assets), as indicated. Investable is a dummy variable that is set equal to one in years in which the firm is designated as investable. DC is an indicator variable, which is 1 if the firm is a dual-class share firm. Firm size as the log of real sales in US\$; growth opportunities is book value of debt plus market capitalization to book assets; tangibility is calculated as fixed assets to total assets, and profitability as earnings before interest, taxation, depreciation and amortization to total assets. Also estimated but not reported are a constant, and a full set of year dummies. Statistical significance is denoted by ***, **, * for the 1, 5 and $10 \%$ levels, respectively. \#Obs is the number of observations.

investability is clearly associated with a lower dependence on debt relative to their non-investable counterparts. However, for DC firms we cannot reject the hypothesis that investability has no effect on debt levels. Even though the sum of the relevant coefficients is negative, it is not significantly different to zero. Therefore debt financing only appears to become less important for SC firms post-liberalization.

An interesting hierarchy of debt employment emerges from this analysis. DC firms are the largest users of debt and in particular non-investable DC firms. Interestingly, the non-significance of the interaction term suggests that investability has roughly the same impact on debt variables whether the firm is SC or DC. However, the magnitudes of the coefficients are such that even though DC firms lower their debt ratios post-liberalization, they still hold more debt than SC firms. So the hierarchy has DC non-investable firms at the top and SC investable firms at the bottom in terms of reliance on debt financing. It is noteworthy that DC firms use more debt financing than their SC counterparts. It could be argued on theoretical grounds that DC firms should use less debt than SC firms, because debt serves to dilute the private benefits of control in the former as creditors can monitor and may impose constraints on the controlling manager's behavior via debt covenants. Our results imply the opposite, with DC firms using relatively more debt financing. This is consistent with the empirical findings of Francis et al. (2005), Dey et al. (2009), and Harvey et al. (2004), who 
show that the greater the ratio of managerial voting to cashflow rights, the greater the use of debt financing. ${ }^{10}$ Similarly, Chong (2010) finds that the greater the discrepancy between voting and cashflow rights in a firm, the greater the use of bank (debt) financing. This preference for debt financing may be due to a number of factors. Billet and Liu (2008) show that, while the cost of bond financing is higher for DC firms (compared with SC firms), ${ }^{11}$ it is still preferred because as the wedge between voting and cashflow rights widens (managers and shareholders' interests diverge), the cost of debt relative to equity declines. Debt may also be preferred as the cost of equity financing is likely to be even higher for these firms, (see Jarrell and Poulson 1988), implying that greater the use of debt financing may not be by choice. The relatively higher employment of debt is also consistent with the notion that debt and 'good' corporate governance are substitutes for one another (see Jensen 1986; and Stulz, 1990). Both Jiraporn and Gleason (2007) and Arping and Sautner (2010) present empirical evidence to support this view. They show that firms reduce their use of debt after corporate governance improvements. Finally, we note that the control variables are, by and large, of the correct sign and statistically significant; larger firms and those with a greater proportion of tangible assets use more debt. Consistent with the pecking order hypothesis, but not the trade-off model, profitable firms use less debt financing.

Table 4 reports coefficient estimates for regressions where the dependent variables are the debt maturity ratios. This allows us to examine the validity of our second hypothesis through an examination of the composition of the debt portfolio. For both groups of firms, there is evidence to support our hypothesis. Focusing on the long- and short-term debt to assets ratios supports our prediction that investability is associated with a lengthening of the debt maturity. However, the way in which this lengthening of the debt maturity is achieved varies between the two types of firm. For DC firms, it is simply a re-balancing of the debt portfolio between long- and short-term debts. Whether measured relative to assets or equity, long-term (short-term) debt increases (decreases) for DC firms post-liberalization. The change in the debt composition for SC firms is somewhat different. SC firms clearly lengthen the maturity of their debt postliberalization as evidenced by the ratio of long-term to total debt. However, it appears that both forms of debt fall - with greater statistical evidence in the case of short-term debt, but short-term debt falls more quickly than long-term debt. The overall effect is consistent with our first hypothesis that SC firms use less debt financing, but that short-term debt becomes relatively less important, leading to less, but, on average, longer-dated debt in their capital structures.

Although they have the highest dependence on debt financing, DC noninvestable firms have the shortest debt maturity, followed by their investable

10 Results differ for developed markets, e.g. using a sample of family-owned Canadian firms, King and Santor (2008) find no significant differences in the amount of debt held by singleand dual-class firms.

11 Chong (2010) and Lin et al. (2011) show that borrowing costs are much higher for firms with excess control rights. 


\section{Effects of Ownership on Corporate Financing}

Table 4 Investability, debt maturity and dual-class firms

\begin{tabular}{|c|c|c|}
\hline & \multicolumn{2}{|c|}{ Debt Maturity Ratio } \\
\hline & $\begin{array}{l}\text { Long-Term Debt } \\
\text { to Total Assets }\end{array}$ & $\begin{array}{c}\text { Short-Term Debt } \\
\text { to Total Assets }\end{array}$ \\
\hline Investable & $0.004(1.30)$ & $-0.017 * * *(6.20)$ \\
\hline Investable $\times$ DC & $0.010 * *(2.04)$ & $-0.001(0.11)$ \\
\hline DC & $-0.020 * * *(4.62)$ & $0.051 * * *(20.08)$ \\
\hline Time dummies and time-invariant effects & Included & Included \\
\hline F-stat (investable + investable $\times$ DC) & $4.28 * *$ & $3.77 *$ \\
\hline \# Obs & 9,803 & 9,803 \\
\hline Controls & Included & Included \\
\hline \multirow[t]{3}{*}{$R^{2}$} & 0.461 & 0.626 \\
\hline & \multicolumn{2}{|c|}{ Debt Maturity Ratio } \\
\hline & $\begin{array}{l}\text { Long-Term Debt } \\
\text { to Equity }\end{array}$ & $\begin{array}{c}\text { Short-Term Debt } \\
\text { to Equity }\end{array}$ \\
\hline Investable & $-0.018 *(1.90)$ & $-0.052 * * *(4.75)$ \\
\hline Investable $\times$ DC & $0.026 *(1.65)$ & $-0.010(0.50)$ \\
\hline DC & $-0.022 *(1.73)$ & $0.118 * * *(11.79)$ \\
\hline Time dummies and time-invariant effects & Included & Included \\
\hline F-stat (investable + investable $\times$ DC) & 0.77 & $5.78^{* *}$ \\
\hline \# Obs & 9,803 & 9,803 \\
\hline Controls & Included & Included \\
\hline \multirow[t]{3}{*}{$R^{2}$} & 0.673 & 0.636 \\
\hline & \multicolumn{2}{|c|}{ Debt Maturity Ratio } \\
\hline & $\begin{array}{l}\text { Long-Term Debt } \\
\text { to Total Debt }\end{array}$ & $\begin{array}{l}\text { Total Debt } \\
\text { to Equity }\end{array}$ \\
\hline Investable & $0.020 * * *(3.34)$ & $-0.025 *(1.66)$ \\
\hline Investable $\times$ DC & $0.001(0.04)$ & $0.010(0.36)$ \\
\hline $\mathrm{DC}$ & $-0.081 * * *(16.68)$ & $0.082 * * *(5.53)$ \\
\hline Time dummies and time-invariant effects & Included & Included \\
\hline F-stat (investable + investable $\times$ DC) & 0.99 & 0.03 \\
\hline \# Obs & 9,803 & 9,803 \\
\hline Controls & Included & Included \\
\hline$R^{2}$ & 0.612 & 0.623 \\
\hline
\end{tabular}

This table reports coefficient estimates from fixed effects vector decomposition regressions with $t$-statistics (absolute value) adjusted for firm-level clustering presented underneath. The dependent variable is long-term debt to assets, long-term debt to equity, long-term debt to total debt, short-term debt to assets, short-term debt to equity, and total debt to equity, as indicated. Investable is a dummy variable that is set equal to 1 in years in which the firm is designated as investable. DC is an indicator variable, which is 1 if the firm is a dual-class share firm. Also estimated, but not reported, are a constant, firm-level controls (size, growth opportunities, tangibility, profitability) and a full set of year dummies. Statistical significance is denoted by $* * *, * *, *$ for the 1,5 and $10 \%$ levels, respectively. \#Obs is the number of observations. 
counterparts. Both SC firm types typically employ longer-maturity debt than DC firms, with investable firms again using, on average, longer-dated instruments than their non-investable equivalents. Hence, it appears that for a given ownership structure (and its associated governance and information regime), becoming investable allows firms to lengthen their debt maturity structure. The lengthening of debt maturity post-liberalization is consistent with Agca et al. (2007), who show that stock market reforms in emerging markets serve to lengthen corporate debt maturity. In contrast, Schmukler and Vesperoni (2006) find that stock market liberalizations (using country-specific dates) are associated with greater use of short-term debt for emerging market firms.

We next focus on hypothesis 3 by examining the ratios of long- and shortterm debts to equity. ${ }^{12}$ From these we can assess the type of substitution effects that are taking place in terms to changes to capital structure. Once more, the results for SC firms are consistent with the financing patterns predicted in hypothesis 3. SC investable firms are found to have the lowest ratio of total debt to equity, suggesting that they use more equity finance as a source of long-term financing post-liberalization. Admittedly, these findings are not definitive proof that SC firms use more equity after becoming investable. For example, in the long-term debt to equity regressions, the negative coefficient may arise because of falling long-term debt, with no change in equity. To try and overcome this shortcoming, we estimate Eq. (3) with net equity issuance ${ }^{13}$ as the dependent variable (unreported). This yields a coefficient on the investable dummy that is positive (0.059), and statistically significant ( $t$-stat is 13.72$)$. Thus, the evidence is consistent with our hypothesis that, post-liberalization SC firms enjoy greater access to equity financing and re-balance their capital structures away from debt instruments. This is consistent with the view that institutional equity investors, foreign investors in this instance, are more likely to invest in firms that practice sound corporate governance (see Ferreira and Matos 2008; Li et al. 2008; Leuz et al. 2009). Focusing specifically on stock market liberalizations, Bae and Goyal (2010) show that better-governed firms enjoy the largest gains from such programs, in terms of stock price revaluations and changes in investment. O'Connor (2012) finds likewise for investable firms from a broader sample of emerging market countries. In contrast, DC firms show no clear pattern postliberalization. They display no tendency to increase the proportion of equity financing employed. In fact, SC non-investable firms still typically have greater equity investment. As discussed earlier, the main change for DC firms is a lengthening of the debt maturity.

As hypothesized, there is a differential effect on capital structure decisions for firms who employ differing ownership structures prior to liberalization. SC firms

12 Table 4 also reports these ratios with total assets as the denominator. However, our findings are similar so we limit our discussion to long- and short-term debts to equity.

13 This is defined as the change in book equity less the change in retained earnings all scaled by book assets as per Baker and Wurgler (2002). A potential shortcoming with this variable is the lack of data availability on 'retained earnings', e.g. we are left with only 3252 firm-year observations remain compared with 9803 in our original sample. 
clearly reap the greater benefits, being able to reduce their debt reliance and lengthen the maturity structure of the debt portfolios. They also appear to substitute debt with equity financing. DC firms, on the other hand, have little changed capital structures post-liberalization, but benefits accrue by a re-balancing of their debt portfolios toward longer-maturity instruments. This alleviates their exposure to rollover risk and short-run liquidity shortages in debt markets.

Furthermore, we observe that DC non-investable firms rely most heavily on debt and in particular, short-term debt financing. Given that their investable counterparts reduce short-term debt reliance post-liberalization, it would appear that they continue to be constrained from accessing longer-maturity markets. This result is consistent with the view that foreign institutional investors are reluctant to invest in poorly governed firms. Where such investment takes place, short-term instruments facilitate greater monitoring and scrutiny of operations.

Combining the results from Tables 3 and 4 suggest that a hierarchy of access to financial markets exists, with well-governed SC firms having fewer restrictions than DC firms. Equity investors favor SC investable firms above all others. The ownership structure, with its associated poor governance and information asymmetries, restricts DC firms to finance their operations largely in debt markets, but firm-specific reforms and investability can be used to gain greater access to long-dated bond markets and hence lengthen the maturity structure of debt. It should also be noted that in both Tables 3 and 4, that the control variables are, by and large, of the correct sign and statistically significant; larger firms and those with a greater proportion of tangible assets use more debt. ${ }^{14}$

\section{ROBUSTNESS CHECKS}

\section{A. Alternative estimation methods}

In Table 5, we reestimate the impact of investability on the debt and debt maturity structures of SC and DC investable firms using a series of alternative estimators which permit the inclusion of time-invariant regressors. We present coefficient estimates using random effects, pooled OLS and pooled OLS using Mundlak (1978) terms (i.e. time averages of the time-variant regressors) included to proxy for unobserved heterogeneity. Results are generally consistent with those reported earlier. SC firms employ less debt after the liberalization event without any statistically significant change in the use of debt for DC firm. Therefore, only SC firms are consistent with the predictions of our first hypothesis. There is some evidence that both SC and DC firms use longer-maturity debt compared with their non-investable counterparts. Now, this pattern is much

14 In unreported regressions, we also show that our results are robust to the inclusion of 'indirect investable' measures, namely international cross-listings in the United States and the introduction of country funds. 


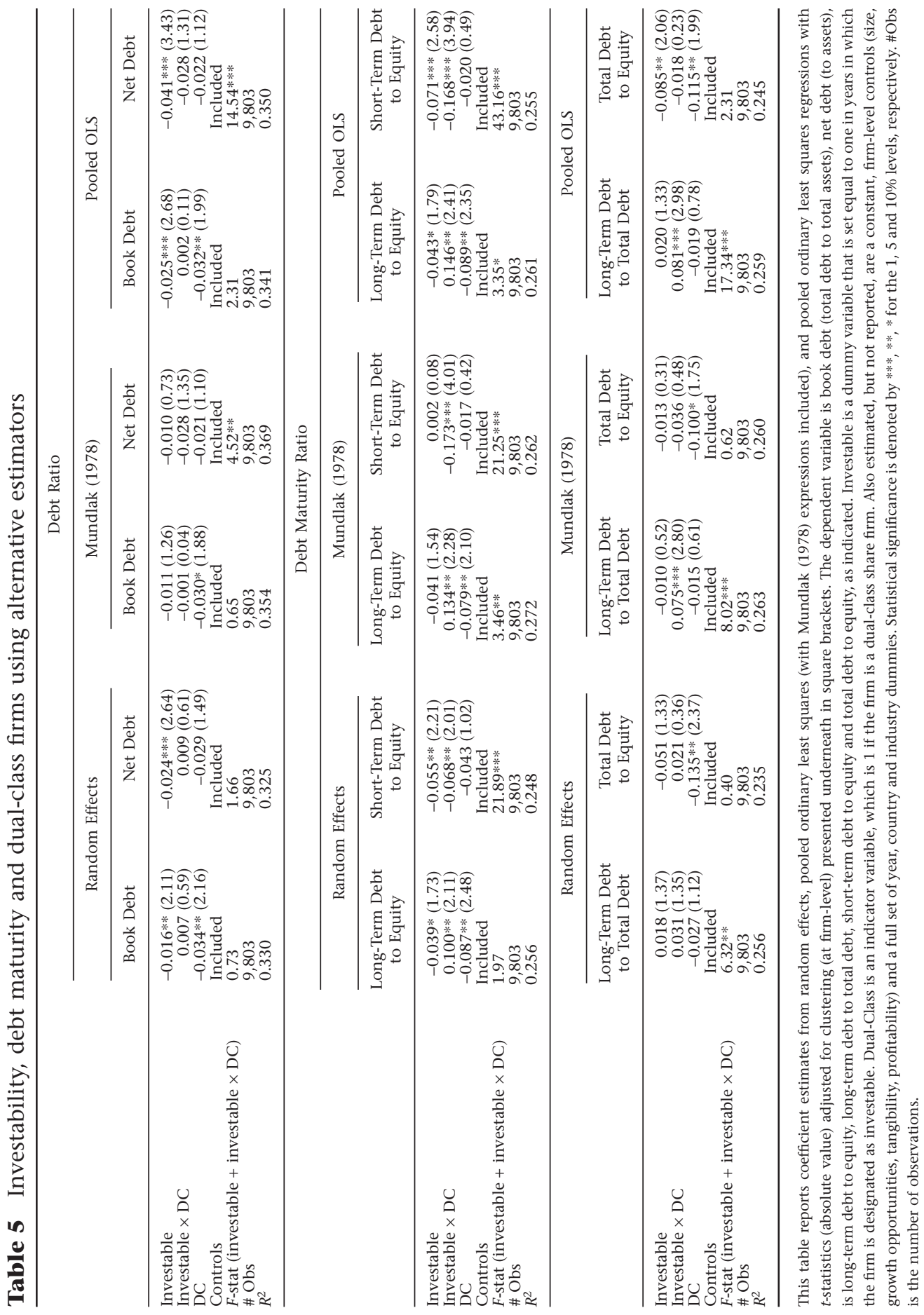


clearer for DC than SC firms. The F-tests for joint significance of the investable firms confirm that investability is associated with a lengthening of the debt maturity structure as predicted by hypothesis 2 . Finally, SC firms appear to shift their capital structures toward equity post-liberalization while DC firms substitute short-term for long-term debt upon becoming investable. Admittedly, the evidence for SC firms is less compelling using these alternative estimators, but nonetheless the coefficient signs are consistent with the earlier story.

An interesting feature of Table 5 is how the coefficient estimate on the DC firm dummy variable in the debt regressions is different in sign from that estimated in the fixed effects vector decomposition regressions. Using random effects, pooled OLS, and pooled OLS using Mundlak (1978) terms, the sign on the dual-class dummy variable is statistically negative, and not positive, as before. These findings suggest that failure to control for unobserved heterogeneity (in the case of pooled OLS), or allow for correlation between the unobserved heterogeneity and the observable variables (in the case of random effects estimation) alters the relationship between firm debt and ownership structure (i.e. single versus dual-class shares). In the case of the Mundlak (1978) regressions, the findings suggest that the Mundlak (1978) terms may not adequately account for the unobserved heterogeneity. Other studies have reported similar findings. Davies et al. (2008) find that the sign on time-invariant variables differs across pooled OLS and FEVD regressions. Lee and Huh (2009) find likewise when they compare random effects and FEVD regressions. This serves to highlight the dangers of not adequately dealing with unobserved heterogeneity and/or its correlation with observed variables.

\section{B. Alternative definition of corporate governance}

Because one potential channel through which the documented effects could materialize is the difference in governance regimes (and associated agency conflicts) that exist between SC and DC firms, we employ an alternative measure of corporate governance to check the robustness of our results. This measure is based on the pre-liberalization proportion of closely held shares in a firm, with higher proportions indicating better governance. Firms with a larger percentage of closely held shares (to total common shares outstanding) are likely to suffer less from agency conflicts since the incentives of the controlling insiders and non-controlling minority outsiders are likely to better aligned. Consistent with this view, Mitton (2002) and Claessens et al. (2002) show how firm profitability and value is greater the larger the ownership (cashflow) stake held by controlling insiders. We divide our sample into quartiles and use the highest (lowest) quartile of 'closely held shares' to proxy for better (poorer) governed firms. ${ }^{15}$ A caveat is that the free-float i.e. the amount of shares

15 We also divided our sample at the median, with the above (below) median group representing relatively better (poorer) governed firms, but found that many firms were located near the median making it difficult to attach any statistical significance to our results. Results are available upon request. 
available to purchase decreases as the controlling stake of the insiders increases. Hence, this potentially biases our coefficients for better-governed firms (i.e. with most closely held shares) because foreign investor participation may be limited, and thus their effect on the firm's capital structure reduced.

In general, the coefficients are less precisely estimated, but the coefficient signs are generally supportive of the earlier reported results. Again, investability is only associated with less reliance on debt for the group of better-governed firms and as such their behavior is consistent with our first hypothesis. However, poorer-governed firms show no reduction in debt financing post investability.

Turning to hypotheses 2 and 3, the results in Table 6 are somewhat mixed. Any concrete conclusions are hampered by the lack of statistical significance attached to the estimates. Firms with better governance regimes reduce both long- and short-term debts (relative to assets and equity) with a quicker decline in shorter maturity instruments. This is consistent with results from before and leads to a lengthening of the maturity of the debt component of financing. Furthermore, there is again some tentative evidence consistent with hypothesis 3 that better governed firms shift toward equity. Taken together, the evidence is broadly consistent with our hypotheses for better-governed firms. In contrast, there is little statistical evidence that investability is associated with any changes in financing behavior for the most poorly governed firms in our sample. Therefore, based on this proxy for governance, the poorly governed firms do not behave as predicted.

\section{CONCLUSION}

We analyze changes to corporate financing behavior of firms who have become investable through firm-specific reforms, but differ in ownership structures before the event. Previous literature has typically treated all firms the same in examining this issue, but we hypothesize that all firms should not be expected to respond homogeneously given that the extant literature has documented important differences between firms with different ownership structures prior to liberalization. Based on well-known theories of the firm, we formulate and test a number of hypotheses of how firms' financing decisions might be expected to behave after a stock market liberalization event. Using firm-specific liberalization dates, we estimate these potentially diverse responses. We adopt a FEVD regression technique, which allows us to include time-invariant variables into our model. The data support all three hypotheses for SC firms, while DC firms behave as predicted in the case of hypotheses 2 and 3, but violate our first hypothesis. Investability allows SC firms to become less reliant on debt financing and to lengthen the maturity of the debt employed relative to noninvestable firms. DC firms show no tendency to change the proportion of debt financing, but we do find evidence of a lengthening of the debt maturity structure. Interestingly, the empirical evidence also suggests that becoming investable confers different advantages on SC and DC firms as predicted by 


\section{Effects of Ownership on Corporate Financing}

Table 6 Investability, debt, debt maturity and corporate governance

\begin{tabular}{|c|c|c|}
\hline & Book Debt & Net Debt \\
\hline Investable & $-0.011 *(1.80)$ & $-0.010 *(1.66)$ \\
\hline Investable $\times$ low governance & $0.005(0.70)$ & $0.005(0.63)$ \\
\hline Low governance & $0.011 * * *(5.65)$ & $-0.025 * * *(10.81)$ \\
\hline Time dummies and time-invariant effects & Included & Included \\
\hline$F$-stat (investable + investable $\times$ low governance) & 0.89 & 0.67 \\
\hline \# Obs & 6,177 & 6,177 \\
\hline \multirow[t]{2}{*}{$R^{2}$} & 0.759 & 0.769 \\
\hline & $\begin{array}{l}\text { Long-Term Debt } \\
\text { to Total Assets }\end{array}$ & $\begin{array}{l}\text { Short-Term Debt } \\
\text { to Total Assets }\end{array}$ \\
\hline Investable & $-0.011(0.22)$ & $-0.010 * *(2.04)$ \\
\hline Investable $\times$ low governance & $0.001(0.03)$ & $0.004(0.96)$ \\
\hline Low governance & $0.098 * * *(32.38)$ & $0.001(0.28)$ \\
\hline Time dummies and time-invariant effects & Included & Included \\
\hline$F$-stat (investable + investable $\times$ low governance) & 0.03 & 0.42 \\
\hline \# Obs & 6,177 & 6,177 \\
\hline \multirow[t]{2}{*}{$R^{2}$} & 0.401 & 0.630 \\
\hline & $\begin{array}{l}\text { Long-Term Debt } \\
\text { to Equity }\end{array}$ & $\begin{array}{l}\text { Short-Term Debt } \\
\text { to Equity }\end{array}$ \\
\hline Investable & $-0.022 *(1.66)$ & $-0.041 * * *(3.25)$ \\
\hline Investable $\times$ low governance & $0.018(0.89)$ & $0.029(1.52)$ \\
\hline Low governance & $0.010(1.24)$ & $0.010(1.52)$ \\
\hline Time dummies and time-invariant effects & Included & Included \\
\hline$F$-stat (investable + investable $\times$ low governance) & 0.06 & 0.55 \\
\hline \# Obs & 6,177 & 6,177 \\
\hline \multirow[t]{2}{*}{$R^{2}$} & 0.659 & 0.647 \\
\hline & $\begin{array}{l}\text { Long-Term Debt } \\
\text { to Total Debt }\end{array}$ & $\begin{array}{l}\text { Total Debt } \\
\text { to Equity }\end{array}$ \\
\hline Investable & $-0.010(0.55)$ & $-0.049 * *(2.43)$ \\
\hline Investable $\times$ low governance & $-0.010(0.57)$ & $0.042(1.55)$ \\
\hline Low governance & $0.068 * * *(21.74)$ & $-0.010(0.76)$ \\
\hline Time dummies and time-invariant effects & Included & Included \\
\hline$F$-stat (investable + investable $\times$ low governance) & 1.24 & 0.11 \\
\hline \# Obs & 6,177 & 6,177 \\
\hline$R^{2}$ & 0.595 & 0.618 \\
\hline
\end{tabular}

This table reports coefficient estimates from fixed effects vector decomposition regressions with $t$-statistics (absolute value) adjusted for firm-level clustering presented underneath. The dependent variable is book debt (total debt to total assets) or net debt (to assets), long-term debt to assets, long-term debt to equity, long-term debt to total debt, short-term debt to assets, short-term debt to equity and total debt to equity, as indicated. Investable is a dummy variable that is set equal to 1 in years in which the firm is designated as investable. Low governance equals 1 if the investable firm's pre-investable (median) closely held shares (as a \% of total shares outstanding) are in the bottom quartile. All investable firms with (median) pre-investable closely held shares (as a \% of total shares outstanding) in the interquartile range are excluded. Firm size as the log of real sales in US\$; growth opportunities is book value of debt plus market capitalization to book assets; tangibility is calculated as fixed assets to total assets, and profitability as earnings before interest, taxation, depreciation and amortization to total assets. Also estimated but not reported are a constant, and a full set of year dummies. Statistical significance is denoted by $* * *, * *, *$ for the 1,5 and $10 \%$ levels, respectively. 
hypothesis 3. Because firms are different prior to the event, their ability to take advantage of their newly liberalized status is also different. Both sets of firms move along the pecking order. In particular, SC firms shift their capital structures by employing less debt and using increasing amounts of equity financing. On the other hand, DC firms change their financing patterns by lengthening the maturity structure of their debt without significantly altering their capital structures. Investability does not enable them to totally overcome the obstacles associated with their ownership structure, but it does remove some of the restrictions in accessing long-maturity sources of finance.

Adopting different estimation techniques and a different proxy for corporate governance provides a largely consistent story, although results based on the alternative measure of governance quality are less precise. Therefore, we can more confidently argue that our results pertain to pre-liberalization ownership structures (SC and DC) and more cautiously to corporate governance. However, issues surrounding the availability of shares for purchase in our 'closely held shares' measure of governance may explain some of the ambiguity in our results.

\author{
Thomas O'Connor \\ Department of Economics, Finance, and Accounting \\ NUI Maynooth \\ Maynooth, Co. Kildare \\ Maynooth 0001 \\ Ireland \\ thomas.g.oconnor@nuim.ie
}

\title{
REFERENCES
}

Agca, S., G. De Nicolo, and E. Detragiache (2007), 'Financial Reforms, Financial Openness, and Corporate Borrowing: International Evidence', IMF Working Paper No. 186, International Monetary Fund, Washington.

Aggarwal, R., I. Erel, M. Ferreira, and P. Matos (2011), 'Does Governance Travel around the World? Evidence from Institutional Investors', Journal of Financial Economics, $100,154-81$.

Akhter, S., and K. Daly (2009), 'Finance and Poverty: Evidence from Fixed Effects Vector Decomposition', Emerging Markets Review, 10, 191-206.

Armstrong, C., K. Balakrishnan, and D. Cohen (2012), 'Corporate Governance and the Information Environment: Evidence from State Antitakeover Provisions', Journal of Accounting and Economics, 53, 185-204.

Arping, S., and Z. Sautner (2010), 'Corporate Governance and Leverage: Evidence from A Natural Experiment', Finance Research Letters, 7, 127-34.

Bae, K., and V. Goyal (2010), 'Equity Market Liberalizations and Corporate Governance', Journal of Corporate Finance, 16, 609-21.

Bae, K., W. Bailey, and C. Mao (2006), 'Stock Market Liberalization and the Information Environment', Journal of International Money and Finance, 25, 404-28.

Baker, M., and J. Wurgler (2002), 'Market Timing and Capital Structure', Journal of Finance, 57, 1-32. 


\section{Effects of Ownership on Corporate Financing}

Barclay, M., and C. Smith (1995), 'The Maturity Structure of Corporate Debt', Journal of Finance, 50, 609-31.

Bharath, S. T., P. Pasquariello, and G. Wu (2009), 'Does Asymmetric Information Drive Capital Structure Decisions?', Review of Financial Studies, 22, 3211-43.

Billet, M., and Y. Liu (2008), 'Shareholder-manager Alignment and the Cost of Debt', Working Paper, University of Iowa.

Chen, T., S. Dasgupta, and Y. Yu (2012), 'Transparency and Financing Choices of Family Firms', Journal of Financial and Quantitative Analysis, (forthcoming).

Chong, B. (2010), "The Impact of Divergence in Voting and Cash-flow Rights on the Use of Bank Debt', Pacific-Basin Finance Journal, 18, 158-74.

Claessens, S., S. Djankov, J. Fan, and L. Lang (2002), 'Disentangling the Incentives and Entrenchment Effects of Large Shareholders', Journal of Finance, 57, 2741-71.

Datta, S., M. Iskandar-Datta, and K. Raman (2005), 'Managerial Stock Ownership and the Maturity Structure of Corporate Debt', Journal of Finance, 60, 2333-50.

Davies, R. B., D. Ionascu, and H. Kristjansdottir (2008), 'Estimating the Impact of Time-Invariant Variables on FDI with Fixed Effects', Review of World Economics, 144, 381-407.

DeAngelo, H., and L. DeAngelo (1985), 'Managerial Ownership of Voting Rights: A Study of Public Corporations with Dual Classes of Common Stock', Journal of Financial Economics, 14, 33-9.

Dey, A., V. Nikolaev, and X. Wang (2009), 'Disproportionate Control Rights and the Bonding Role of Debt', Working Paper, University of Chicago.

Durnev, A., and E. Kim (2005), 'To Steal or Not to Steal: Firm Attributes, Legal Environment, and Valuation', Journal of Finance, 60, 1461-93.

Ferreira, M., and P. Matos (2008), 'The Colours of Investors' Money: The Role of Institutional Investors around the World', Journal of Financial Economics, 88, 499533.

Flavin, T., and T. O'Connor (2010), 'The Sequencing of Stock Market Liberalization Events and Corporate Financing Decisions', Emerging Markets Review, 11, 183-204.

Francis, J., K. Schipper, and L. Vincent (2005), 'Earnings and Dividends Informativeness When Cashflow Rights Are Separated from Voting Rights', Journal of Accounting and Economics, 39, 329-60.

Grossman, S., and O. Hart (1982), 'Corporate Financial Structure and Managerial Incentives, in John McCall (ed)', The Economics of Information and Uncertainty, Chicago, IL: University of Chicago Press, pp. 107-140.

Grossman, S., and O. Hart (1988), 'One Share-one Vote and the Market for Corporate Control', Journal of Financial Economics, 20, 175-202.

Guney, Y., and A. Ozkan (2005), 'New Insights on the Importance of Agency Costs for Corporate Debt Maturity Decisions', Applied Financial Economics, 1, 233-8.

Harvey, C., K. Lins, and A. Roper (2004), 'The Effect of Capital Structure When Expected Agency Costs Are Extreme', Journal of Financial Economics, 74, 3-30.

Henry, P. B. (2000), 'Do Stock Market Liberalizations Cause Investment Booms?', Journal of Financial Economics, 58, 301-34.

Jarrell, G., and A. Poulson (1988), 'Dual-class Share Recapitalizations As Antitakeover Mechanisms: The Recent Evidence', Journal of Financial Economics, 20, 129-52.

Jensen, M., and W., Meckling (1976), 'Theory of the Firm: Managerial Behavior, Agency Costs, and Ownership Structure', Journal of Financial Economics, 3, 305-360.

Jensen, M. (1986), 'Agency Costs of Free Cash Flow, Corporate Finance and Takeovers', American Economic Review, 76, 323-9.

Jiraporn, P., and K. Gleason (2007), 'Capital Structure, Shareholder Rights, and Corporate Governance', Journal of Financial Research, 30, 21-33. 
Jiraporn, P., J.-C. Kim, Y. S. Kim, and P. Kitsabunnarat (2012), 'Capital Structure and Corporate Governance Quality: Evidence from the Institutional Shareholder Services (ISS)', International Review of Economics and Finance, 22, 208-21.

Khurana, I. K., X. Martin, and R. Periera (2008), 'Cross-listing and Firm Growth', Review of Finance, 12, 293-322.

Kim, E., and V. Singal (2000), 'Stock Market Openings: Experience of Emerging Economies', Journal of Business, 73, 25-66.

King, M., and E. Santor (2008), 'Family Values: Ownership Structure, Performance and Capital Structure of Canadian Firms', Journal of Banking and Finance, 32, 242332.

Lang, M. H., K. V. Lins, and D. P. Miller (2003), 'Adrs, Analysts and Accuracy - Does Cross-listing in the U.S. Improve A Firm's Information Environment and Increase Market Value?', The Journal of Accounting Research, 41, 317-45.

Lee, H., and H. Huh (2009), 'Two-way Flows of Financial Assets and Their Implications for Financial Cooperation in East Asia', Kangwon National University, Working Paper.

Lensink, R., and R. van der Molen (2010), 'Does Group Affiliation Increase Firm Value for Diversified Groups? New Evidence from Indian Companies', Journal of Empirical Finance, 17, 332-44.

Leuz, C., K. Lins, and F. Warnock (2009), 'Do Foreigners Invest Less in Poorly Governed Firms?', Review of Financial Studies, 22, 2393-421.

Li, K., H. Ortiz-Molina, and X. Zhao (2008), 'Do Voting Rights Affect Institutional Investment Decisions? Evidence from Dual-Class Firms', Financial Management, 37, 713-45.

Li, T., and N. Zaiats (2012), 'Corporate Governance of Dual-class Firms', Working Paper, University of Wisconsin-Milwaukee.

Li, T., L. Ng, N. Zaiats, and B. Zhang (2012), 'Information Environment, Earnings Management, and Dual-class Firms: A Cross-country Analysis', Working Paper, University of Wisconsin-Milwaukee.

Lim, L. (2010), 'Dual-class versus Single-class Firms: Information Environment', PhD Thesis, The George Washington University.

Lin, C., Y. Ma, P. Malatesta, and Y. Xuan (2011), 'Ownership Structure and the Cost of Corporate Borrowing', Journal of Finance, 100, 1-23.

Lins, K. (2003), 'Equity Ownership and Firm Value in Emerging Markets', Journal of Financial and Quantitative Analysis, 38, 159-84.

Lins, K., D. Strickland, and M. Zenner (2005), 'Do Non-U.S. Firms Issue Equity on U.S. Stock Exchanges to Relax Capital Constraints?', Journal of Financial and Quantitative Analysis, 40, 109-33.

Masulis, R., C. Wang, and F. Xie (2009), 'Agency Costs at Dual-class Companies', Journal of Finance, 64, 1697-727.

Mitton, T. (2002), 'A Cross-Firm Analysis of the Impact of Corporate Governance on the East Asian Financial Crisis', Journal of Financial Economics, 64, 215-41.

Mitton, T. (2006), 'Stock Market Liberalization and Operating Performance at the Firm Level', Journal of Financial Economics, 81, 625-47.

Mitton, T. (2007), 'Why Have Debt Ratios Increased for Firms in Emerging Markets?', European Financial Management, 14, 127-51.

Mitton, T., and T. O'Connor (2012), 'Investability and Firm Value', European Financial Management, 18, 731-61.

Mundlak, Y. (1978), 'On the Pooling of Time Series and Cross Section Data', Econometrica, 1, 69-85.

Myers, S., and N. Majluf (1984), 'Corporate Financing and Investment Decisions When Firms Have Information That Investors Do Not Have', Journal of Financial Economics, 13, 187-221. 


\section{Effects of Ownership on Corporate Financing}

O'Connor, T. (2012), 'Investability, Corporate Governance, and Firm Value', Research in International Business and Finance, 26, 120-36.

Pindado, J., and C. de la Torre (2011), 'Capital Structure: New Evidence from the Ownership Structure', International Review of Finance, 11, 213-26.

Plumper, T., and V. Troeger (2007), 'Efficient Estimation of Time-invariant and Rarely Changing Variables in Finite Sample Panel Analyses with Unit Fixed Effects', Political Analysis, 15, 124-39.

Plumper, T., and V. Troeger (2011), 'Fixed Effects Vector Decomposition: Properties, Reliability, and Instruments', Political Analysis, 19, 147-64.

Roberts, M. R., and T. Whited (2012), 'Endogeneity in Empirical Corporate Finance', Simon School Working Paper no. FR 11-29.

Schmukler, S. L., and E. Vesperoni (2006), 'Financial Globalization and Debt Maturity in Emerging Markets', Journal of Development Economics, 79, 183-207.

Stulz, R. (1990), 'Managerial Discretion and Optimal Financing Policies', Journal of Financial Economics, 26, 3-27. 